\title{
Expression of $3 \beta$-hydroxysteroid dehydrogenase and P450 aromatase in porcine oviduct during the oestrous cycle
}

\author{
M. Martyniak, K. Zglejc, A. Franczak and G. Kotwica ${ }^{1}$ \\ University of Warmia and Mazury in Olsztyn, Department of Animal Physiology \\ Oczapowskiego 1A, 10-719 Olsztyn-Kortowo, Poland
}

KEY WORDS: oviduct, P450 aromatase, 3ß-hydroxysteroid dehydrogenase, steroidogenesis, pig

Received: 2 December 2015

Revised: $\quad 12$ April 2016

Accepted: 26 August 2016

${ }^{1}$ Corresponding author:

e-mail: gkotwica@uwm.edu.pl

\begin{abstract}
Steroid hormones regulate the oviductal functions in cyclic pigs. The mRNA and protein steroidogenic enzymes expression - 3ß-hydroxysteroid dehydrogenase (HSD3B), encoded by HSD3B and P450 aromatase (P450arom), encoded by CYP19, were studied in ampulla and isthmus of pig oviducts during luteal (days 2-3, $10-11$ and $15-16$ ) and follicular (days 18 - 20) phase. Expression of HSD3B in ampulla was greater on days 2-3,12-13 and 18-20 vs $10-11$ and $15-16$. In isthmus it was greater on days $2-3$ vs $10-11$ and on days 18 - 20 vs $10-11$ to $15-16$. Proteins were immunolocalized in epithelial cells of ampulla and isthmus. On days 15 - 16, HSD3B concentration in ampulla was the greatest, in isthmus it was greater on days $15-16$ vs $12-13$. The P450arom protein expression was the greatest on days $2-3$ in ampulla and isthmus and thereafter it gradually declined toward the end of the oestrous cycle. Progesterone concentration $\left(\mathrm{pg} \cdot \mathrm{ml}^{-1}\right)$ in oviductal flushings did not change from days $2-3(960.2 \pm 367.2)$ to $15-16(543.4 \pm 235.3)$, but decreased on days 18 - 20 (154.5 \pm 34.8$)$. Androstenedione concentration $\left(\mathrm{pg} \cdot \mathrm{ml}^{-1}\right)$ on days $2-3$ (726.4 \pm 108.4$)$ and $18-20(701.0 \pm 59.0)$, and oestradiol-17ß $\left(\mathrm{pg} \cdot \mathrm{ml}^{-1}\right)$ levels on days $12-13(104.1 \pm 9.6)$ and $18-20(110.4 \pm 14.4)$ were greater than on other days. This study showed, that expression of mRNA and proteins of steroidogenic enzymes in oviduct of cyclic pigs depends on the stage of the oestrous cycle. This observation suggests ability of porcine oviduct to de novo synthesize steroid hormones.
\end{abstract}

\section{Introduction}

Steroid hormones, mainly progesterone $(\mathrm{P} 4)$ and oestradiol-17ß (E2), affect oviduct functioning in pigs and other species (Hunter, 1991, 2012; Hunter et al., 1999; Chen et al., 2013). These steroids affect gene expression, cells ultrastructure and differentiation, motility of oviduct, as well as the composition and volume of oviductal fluid during the oestrous cycle (Rodriguez-Martinez et al., 1982; Buhi, 2002; Yaniz et al., 2006; Carrasco et al., 2008; Skowronski et al., 2011; Hunter, 2012). Thus, steroids regulate oviductal microenvironment and support maturation of gametes, fertilization and early embryonic development (Hunter et al., 1999; Wollenhaupt et al., 2001; Buhi, 2002; Georgiou et al., 2005; Brüssow et al., 2008; Chen et al., 2013). The embryos stay in oviduct only for 2-3 days after fertilization (Hunter, 1974), so most of the oviduct physiological adaptations should occur before and around ovulation in pig. Therefore, steroid hormones can be secreted by the oviduct during the oestrous cycle and, as a local regulators, prepare the organ for its physiological functions. 
The steroidogenesis is regulated by $3 \beta$-hydroxysteroid dehydrogenase (HSD3B) and aromatase cytochrome P450 (P450arom), which are encoded by $H S D 3 B$ and $C Y P 19$ genes, respectively (Graddy et al., 2000; LaVoie and King, 2009). Conversion of pregnenolone into $\mathrm{P} 4$ and androgens into oestrogens (among which $\mathrm{E} 2$ exerts the most pronounced effects) is catalysed by HSD3B and P450arom, respectively. Steroidogenic enzymes may be differentially expressed in ampulla and isthmus, since these compartments are characterized by diverse ultrastructure of mucosa in pigs (Yaniz et al., 2006) in order to prepare the oviduct for specific functioning during periovulatory period (Rodriguez-Martinez et al., 1982; Hunter, 1991; Hunter et al., 1999; Killian, 2011).

The ovaries, and to a lesser extent, peritoneal fluid as well as ovulated cumulus-oocyte complexes arriving in the oviduct, are the source of P4 and E2 found inside the oviduct (Hunter, 2012). Moreover, the counter-current transfer of ovarian steroids including P4, androstenedione (A4) and E2 from venous blood, interstitial fluid and lymph to the arterial blood supplying the oviduct has been shown in pigs (Stefańczyk-Krzymowska and Krzymowski, 2002). In addition, it was demonstrated that steroid enzymes mRNA and protein are expressed in uterine tissues and steroids are secreted by isolated uterine cells and explants from cyclic pigs (Franczak, 2008; Franczak and Kotwica, 2010; Wojciechowicz et al., 2013; Franczak et al., 2014). Oviductal synthesis of steroid hormones in pigs is still unknown.

Therefore, the aim of this study was to verify the hypothesis that steroids could be de novo synthesised by porcine oviduct. For this purpose we investigated: 1. the expression of $H S D 3 B$ and CYP19 mRNA, and HSD3B and P450arom proteins in ampulla and isthmus and 2. concentrations of P4, A4 and E2 in oviductal flushings of gilts on days 2-3,10-11, $12-13,15-16$ and $18-20$ of the oestrous cycle.

\section{Material and methods}

\section{Tissues and flushings collection}

All experiments were approved by the Animal Ethics Committee of University of Warmia and Mazury in Olsztyn (Poland). The oviducts were harvested from gilts (Large White $\times$ Polish Landrace, $90-110 \mathrm{~kg}$ body weight), on days $2-3,10-11,12-13$, $15-16$ and $18-20$ of the oestrous cycle $(n=5 /$ each period). The selected days of the oestrous cycle are related to early- (days 2-3), mid- (days 10-11 and 12-13) and late- (days 15-16) luteal phase and days 18-20 represent follicular phase. The origin and maintenance of gilts and the verification of the day of the oestrous cycle were described previously (Franczak, 2008; Wojciechowicz et al., 2013). Immediately after slaughter, each oviduct was isolated, flushed with $2 \mathrm{ml}$ of sterile saline and then ampulla and isthmus were excised. Oviductal flushings were frozen at $-20^{\circ} \mathrm{C}$ for further determination of $\mathrm{P} 4, \mathrm{~A} 4$ and $\mathrm{E} 2$ concentrations. Oviducts were divided into ampulla and isthmus (Hunter, 2012), frozen in liquid nitrogen and then stored at $-80{ }^{\circ} \mathrm{C}$ until further determination of $H S D 3 B$ and CYP19 mRNAs levels as well as HSD3B and P450arom proteins expression.

\section{Validation of reference genes and determination of $H S D 3 B$ and $C Y P 19$ mRNAs expression in ampulla and isthmus of oviducts}

Total RNA was extracted from ampulla and isthmus with the use of TRIzol method supplemented with DNase (Qiagen, Hilden, Germany) treatment. Concentration and purity of isolated RNA were verified with spectrophotometry (NanoDrop ND1000, Thermo Fisher Scientific, Waltham, MA, USA). Total RNA was transcribed into cDNA during the reverse transcription reaction process (RT) using QuantiTect Reverse Transcription Kit (Qiagen, Hilden, Germany). Procedure was as follows: $1 \mu \mathrm{g}$ of isolated RNA, $2 \mu \mathrm{g}$ of gDNA Wipeout Buffer and $14 \mu 1$ of RNase free water were added to the tube and incubated at $42{ }^{\circ} \mathrm{C}$ for $15 \mathrm{~min}$. Then, $1 \mu 1$ of Quantiscript Reverse Transriptase, $4 \mu 1$ of Quantiscript $5 \times$ RT buffer and $1 \mu 1$ of RT primers were added to each sample and all was incubated at $42{ }^{\circ} \mathrm{C}$ for $15 \mathrm{~min}$ followed by incubation at $95{ }^{\circ} \mathrm{C}$ for $3 \mathrm{~min}$. After reverse transcription reaction each sample was diluted in nuclease free water to the concentration $200 \mathrm{ng} \cdot \mu \mathrm{l}^{-1}$ and used for Real-Time PCR analysis.

Validation of the housekeeping genes for study HSD $3 B$ and CYP19 mRNA expression was performed according to Goossens et al. (2005), Rekawiecki et al. (2013) and Nelis et al. (2015b). Primers for housekeeping and studied genes (Table 1) were designed using Primer BLAST software (NCBI, Rockville Pike, Bethesda, MD, USA), and specificity of genes was confirmed by PerlPrimer software (Parkvile, Victoria, Australia).

Real-Time PCR for validation of reference genes and determination of HSD $3 B$ and CYP19 mRNA expression was performed in duplicate for each sample, using a 7300 Real time PCR System and SYBR $^{\circledR}$ Green PCR Master Mix (both Life Technologies; 
Table 1. Forward and reverse primers sequences, amplicons length and GeneBank accession numbers of genes used during Real-Time PCR analysis

\begin{tabular}{|c|c|c|c|}
\hline Name of the gene & $\begin{array}{l}\text { Primer sequence } \\
\text { forward/reverse }\end{array}$ & $\begin{array}{l}\text { Amplicon } \\
\text { length, bp }\end{array}$ & $\begin{array}{l}\text { Accession } \\
\text { number }\end{array}$ \\
\hline Ubiquitin C (UBC) & $\begin{array}{l}\text { 5' GGAGGAATCTACTGGGGCGG 3' } \\
\text { 5' CAGAAGAAACGCAGGCAAACT 3' }\end{array}$ & 103 & XM_003483411.3 \\
\hline Large ribosomal protein 32 (RPL32) & $\begin{array}{l}\text { 5' CAGACCCCTTGTGAAGCC 3' } \\
\text { 5' CCTGTTGTCAATGCCTCT 3' }\end{array}$ & 121 & NM_001001636.1 \\
\hline Beta-actin (ACTB) & $\begin{array}{l}\text { 5' CACGCCATCCTGCGTCTGGA 3' } \\
\text { 5' AGCACCGTGTTGGCGTAGAG 3' }\end{array}$ & 380 & XM_003357928.2 \\
\hline Hydroxymethylbilane synthase (HMBS) & $\begin{array}{l}\text { 5' GAGCCAAGGACCAGGACATC 3' } \\
\text { 5' CCAGTCAGGTAGAGTTGC 3' }\end{array}$ & 166 & NM_001097412.1 \\
\hline Beta-2-microglobulin (B2M) & $\begin{array}{l}\text { 5' TCGGGCTGCTCTCACTGTCT 3' } \\
\text { 5' GGCGYGAGTAAACCTGAACCTT 3' }\end{array}$ & 69 & NM_213978 \\
\hline Hypoxanthine phosphoribosyltransferase 1 (HPRT1) & $\begin{array}{l}\text { 5' AGCGYCGTGATTAGTGAT 3' } \\
\text { 5' CACAGAGGGCTACGATGT 3' }\end{array}$ & 181 & NM_001032376.2 \\
\hline Glyceraldehyde-3-phosphatedehydrogenase (GAPDH) & $\begin{array}{l}\text { 5' CATCAATGGAAAGGCCATCAC 3' } \\
\text { 5' CAGCATCGCCCCATTTG 3' }\end{array}$ & 68 & KJ786424.1 \\
\hline 18 S ribosomal RNA (18SRNA) & $\begin{array}{l}\text { 5' TCCAATGGATCCTCGCGGAA 3' } \\
\text { 5' GGCTACCACATCCAAGGAAG 3' }\end{array}$ & 149 & AY265350.1 \\
\hline 3-ßhydroxysteroid dehydrogenase (HSD3B) & $\begin{array}{l}\text { 5' GTGAAAGGTACCCAGCTCCTGC 3' } \\
\text { 5' GCGTTCTGGATGACCTCCCT 3' }\end{array}$ & 119 & NM_001004049.1 \\
\hline Cytochrome P450 aromatase (CYP19) & $\begin{array}{l}\text { 5' TGAGGTACCAGCCTGTCGTGGA 3' } \\
\text { 5' ATTTGGCTTTGGGCCCCGGG 3' }\end{array}$ & 216 & NM_214431.1 \\
\hline
\end{tabular}

Carlsbad, CA, USA). The conditions of Real-Time PCR analysis were similar to these described by Wojciechowicz et al. (2013) and Dziekoński et al. (2015). The mean $\mathrm{Ct}$ values for each housekeeping gene were transformed using the comparative $\Delta \mathrm{Ct}$ method with the following equation: $\mathrm{Q}=\mathrm{E}^{-\Delta \mathrm{Ct}}$. The $Q$ value is a relative quantity of gene expression, the $\mathrm{E}$ value is the reaction efficiency and the $\Delta \mathrm{Ct}=\mathrm{Ct}$ of housekeeping gene $-\mathrm{Ct}$ of studied gene (where $\mathrm{Ct}$ of housekeeping gene is the $\mathrm{Ct}$ value for each reference gene and $\mathrm{Ct}$ of studied gene is $\mathrm{Ct}$ value of $H S D 3 B$ or CYP19). Relative gene expression data were analysed using the NormFinder Microsoft Excel applet (Aarhus, Central Jutland, Denmark). The specificity of the obtained PCR products was confirmed by gel electrophoresis and sequencing (Genomed; Warsaw, Poland). Expression of HSD $3 B$ and CYP19 was calculated in reference to $\beta$-actin $(A C T B)$ and ubiquitin $\mathrm{C}(U B C)$ by $\triangle \triangle \mathrm{Ct}$ method. All data are presented in arbitrary units.

\section{Immunolocalization of HSD3B and $\mathbf{P 4 5 0 a r o m}$ proteins in the porcine oviducts}

Immunofluorescent study of HSD3B and P450arom protein in oviducts and calculation of data were done according to Franczak et al. (2014) with some modifications. In short, explants of oviducts divided into ampulla and isthmus were transferred from $-80{ }^{\circ} \mathrm{C}$ to $-20{ }^{\circ} \mathrm{C}$ and incubated for $12-16 \mathrm{~h}$. Then, tissues were cut with the cryostat (Thermo Fisher Scientific; Waltham, MA, USA) into $7-\mu \mathrm{m}$ thick slices. Prepared slices were fixed in 4\% paraformaldehyde, incubated with goat serum for $1 \mathrm{~h}$ at $4{ }^{\circ} \mathrm{C}$, washed with PBS, and incubated overnight at $4{ }^{\circ} \mathrm{C}$ with primary antibodies followed by onehour incubation at room temperature with secondary antibody (Table 2). After final washing with PBS, the slices were covered with Fluoroshield, containing DAPI (4',6-diamidino-2-phenylindole) to visualize nuclei of stained cells (Sigma Aldrich; St. Louis, MO, USA). Stained ampulla and isthmus slices were examined under an epifluorescent microscope (BX51; Olympus, Shinjuku, Tokyo, Japan). Pictures were taken at the 500× magnification and fluorescence intensity was examined with $\mathrm{Cell}^{\wedge} \mathrm{F}$ software version 3.4 (Olympus, Shinjuku, Tokyo, Japan). Intensity of fluorescent staining was measured in four technical replicates in each of five biological replicates within one studied group. The areas of fluorescence emission in each technical replicate were marked by applying a colour mask that covers specific colour intensity in the images (the same threshold for each image). Fluorescent intensity was measured in randomly chosen eight regions of interest. Then, the mean of fluorescent intensity staining, representing the relative quantity of HSD3B and P450arom proteins, was calculated. 
Table 2. Antibodies used during immunolocalization procedure

\begin{tabular}{|c|c|c|c|c|}
\hline Antibody & Type & Concentration & Homology & Company \\
\hline $\begin{array}{l}\text { Cytochrome } \mathrm{P} 450 \text { aromatase } \\
\text { (P450arom), rabbit anti-human }\end{array}$ & $\begin{array}{l}\text { Primary, } \\
\text { polyclonal }\end{array}$ & $1: 200$ & $\begin{array}{l}82 \% \text { homology to porcine } \mathrm{P} 450 \text { aromA1 and } \\
81 \% \text { homology to porcine } \mathrm{P} 450 \mathrm{aromA} 3\end{array}$ & $\begin{array}{l}\text { Sigma Aldrich (St. Louis, } \\
\text { MO, USA) }\end{array}$ \\
\hline $\begin{array}{l}\text { 33-hydroxysteroid dehydrogenase } \\
\text { (HSD3B), rabbit anti-human }\end{array}$ & $\begin{array}{l}\text { Primary, } \\
\text { polyclonal }\end{array}$ & $1: 200$ & $89 \%$ homology to porcine HSD3B7 & $\begin{array}{l}\text { Sigma Aldrich (St. Louis, } \\
\text { MO, USA) }\end{array}$ \\
\hline Alexa Fluor 555, anti-rabbit & Secondary & $1: 1500$ & - & $\begin{array}{l}\text { Life Technologies } \\
\text { (Carlsbad, CA, USA) }\end{array}$ \\
\hline
\end{tabular}

\section{Determination of steroid hormones concentration in oviductal flushings}

The concentrations of P4, A4 and E2 in oviductal flushings were determined in duplicate by radioimmunoassay (RIA) (Ciereszko, 1999; Szafrańska et al., 2002). The extraction efficiencies ( $\mathrm{n}=4$ - 5 oviductal flushings / day / each hormone) were: $\mathrm{P} 4-85.7 \pm 0.01 \%, \mathrm{~A} 4-87.9 \pm 0.01 \%$ and $\mathrm{E} 2-91.8 \pm 0.01 \%$. The sensitivity of every assay was 1 pg per sample. The intra-assay coefficients of variation were $0.3 \%, 1.1 \%$ and $0.8 \%$ for $\mathrm{P} 4, \mathrm{~A} 4$ and E2, respectively. The inter-assay coefficient of variation for $\mathrm{P} 4$ was $3.9 \%$ and $\mathrm{A} 4$ and $\mathrm{E} 2$ levels were determined each in one assay, so this coefficient does not exist.

\section{Statistical analysis}

Data were expressed as the mean \pm standard error of the mean (SEM) and values at $P<0.05$ were considered as statistically significant (Statistica 10.0 software Statsoft Inc., Tulsa, OK, USA). The statistical analyses of HSD $3 B$ and CYP19 mRNA levels and HSD3B and P450arom protein expression to compare the obtained results between different days were performed using one-way analysis of variance (ANOVA), followed by the NIR Fisher post-hoc test (the least significant differences test). Pearson's coefficient was used in correlation analysis. Concentrations of P4, A4 and E2 were log-transformed to reduce heterogeneity of variance and then were analysed by one-way ANOVA.

\section{Results}

\section{Reference genes selection}

From genes used for Real-Time PCR analysis validation the most stable were beta-2-microglobulin $(B 2 M)$ and $A C T B$ (stability value $=0.164$ ) and $A C T B$ and $U B C$ (stability value $=0.197$ ) for $H S D 3 B$ and $C Y P 19$ mRNA analysis, respectively (Table 3 ). The combination of $A C T B+U B C$ was chosen to calculate $H S D 3 B$ and $C Y P 19$ mRNA expression in oviductal tissues.
Table 3. Stability values of housekeeping genes in reference to $3 \beta$-hydroxysteroid dehydrogenase (HSD3B) and P450 aromatase (CYP19) mRNA analysis

\begin{tabular}{lll}
\hline $\begin{array}{l}\text { Name } \\
\text { of reference gene }\end{array}$ & The stability value & \\
\cline { 2 - 3 } & HSD3B & CYP19 \\
\hline UBC & 0.368 & 0.261 \\
RPL32 & 0.352 & 0.304 \\
HMBS & 0.368 & - \\
ACTB & 0.221 & 0.458 \\
B2M & 0.305 & 0.263 \\
HPRT1 & 0.263 & - \\
GAPDH & 0.464 & - \\
18SRNA & 0.387 & 0.337 \\
\hline
\end{tabular}

\section{Expression of $H S D 3 B$ and $C Y P 19$ mRNA in ampulla and isthmus}

$H S D 3 B$ expression (Figure 1A) was elevated in ampulla on days $2-3$ (880\% and 238\%), $12-13$ (971\% and $262 \%)$ and $18-20(1171 \%$ and $316 \%)$ in relation to days $10-11$ and $15-16$, respectively. In isthmus this expression was elevated $(P<0.05)$ on days 2 - 3 (234\%) vs days $10-11$ and on days 18-20 compared to days $10-11,12-13$ and $15-16(356 \%$, $270 \%$ and $237 \%$, respectively). Expression of $H S D 3 B$ mRNA in ampulla and isthmus was positively correlated $(r=0.603 ; P<0.05)$. From days 2-3 to days 15-16 the CYP19 expression was stable in ampulla (Figure 1B) and then it increased $(P<0.05)$ on days $18-20$ in relation to $2-3,10-11$, $12-13$ and $15-16$ days of the oestrous cycle $(726 \%$, $507 \%, 845 \%$ and $351 \%$, respectively). In isthmus CYP19 mRNA expression was greater $(P<0.05)$ on days 15-16 in comparison to days $2-3,10-11$, $12-13$ and $18-20(476 \%, 697 \%, 258 \%$ and $628 \%$, respectively). On days 15-16 and 18-20 of the oestrous cycle the CYP19 expression in ampulla and isthmus was different $(P<0.05)$.

Specificity of amplified DNA sequences of $H S D 3 B$ and CYP19 in ampulla and isthmus of the porcine oviduct indicated 99\% homology with Sus scrofa HSD3B1 mRNA (access No. NM 001004049.1), 98\% homology with Sus scrofa CYP19A1 and CYP19A2 

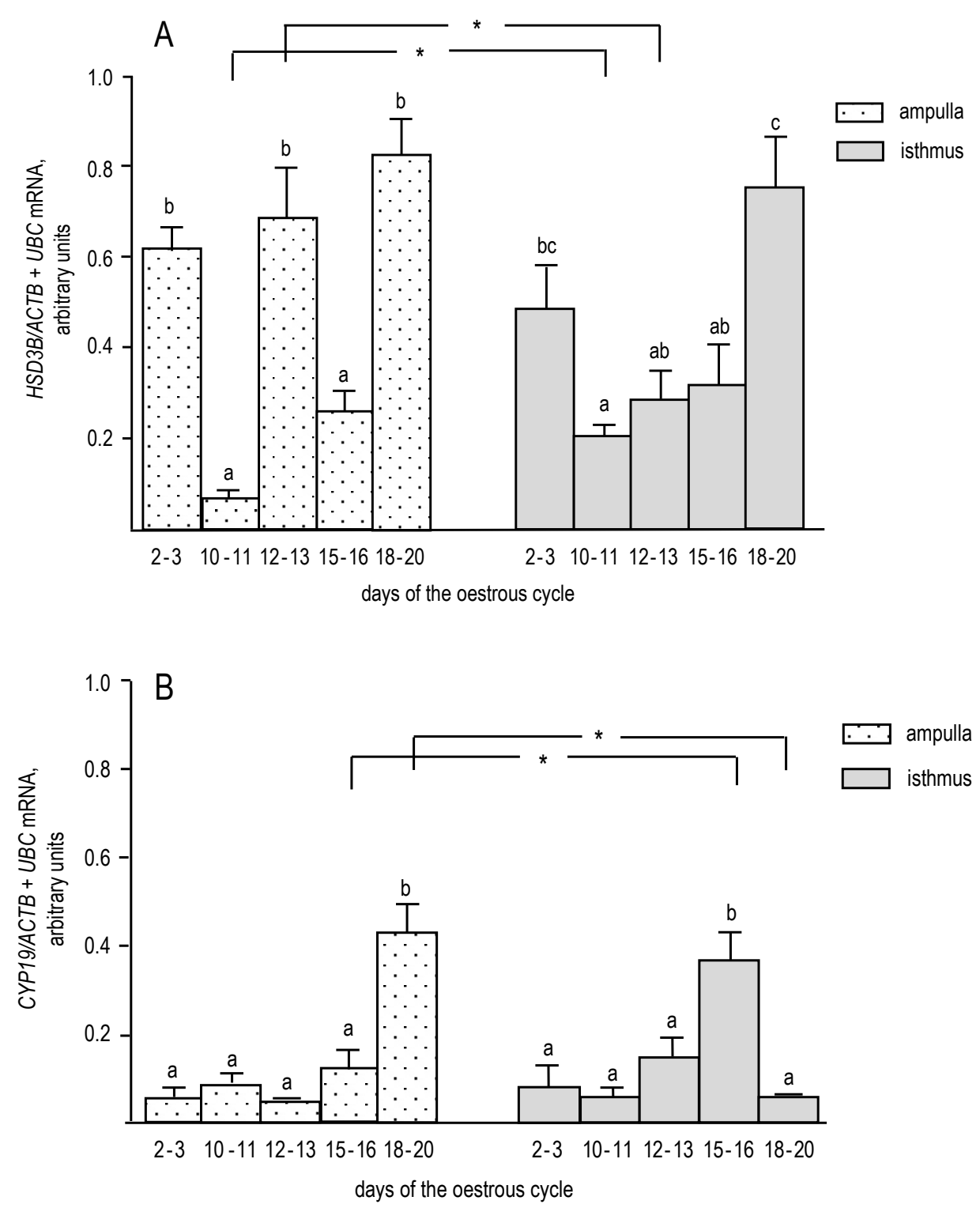

Figure 1. Relative expression of the HSD3B (A) and CYP19 (B) genes in ampulla and isthmus of oviduct in gilts during the oestrous cycle ( $n=5$ per period). ${ }^{\text {abc }}$ - bars with different superscripts are significantly different at $P<0.05$ for ampulla or isthmus separately; ${ }^{*}-$ indicates significant difference between ampulla and isthmus during the same days of the oestrous cycle

mRNAs (access No. NM 214429.1 and NM 214430.1, respectively) and 97\% homology with Sus scrofa CYP19A3 (access No. 214431.1).

\section{Immunolocalization and expression of HSD3B and P450arom proteins in ampulla and isthmus}

HSD3B and P450arom proteins were localized mainly in epithelial cells of ampulla and isthmus. Weak positive signals of immunostaining were found in the lamina propria and tunica muscularis, but not in the lumen (Figure $2-\mathrm{A}, \mathrm{B}$ ). The HSD3B protein expression in ampulla was similar $(P>0.05)$ from days $2-3$ to $12-13$, then it increased $(P<0.05)$ on days 15-16 and again decreased on days 18-20 to the level similar to days $10-11$ and $12-13$ (Figure 2A). In isthmus only difference $(P<0.05)$ between days $12-13$ and $15-16$ was observed in HSD3B expression. On days $2-3$ HSD3B protein expression was greater $(P<0.05)$ in isthmus than in ampulla. The expression of $\mathrm{P} 450$ arom protein both in ampulla and isthmus was the greatest $(P<0.05)$ on days 2-3 (Figure 2B) compared to other days. In ampulla, P450arom protein expression did not differ $(P>0.05)$ from days $10-11$ to $18-20$ and in isthmus on days 12-13 and 18-20 expression was lesser $(P<0.05)$ than on days $2-3$ and $10-11$. Significant correlations $(P<0.05)$ of HSD3B $(r=0.448)$ and P450arom $(r=0.402)$ protein expression between ampulla and isthmus were found. 

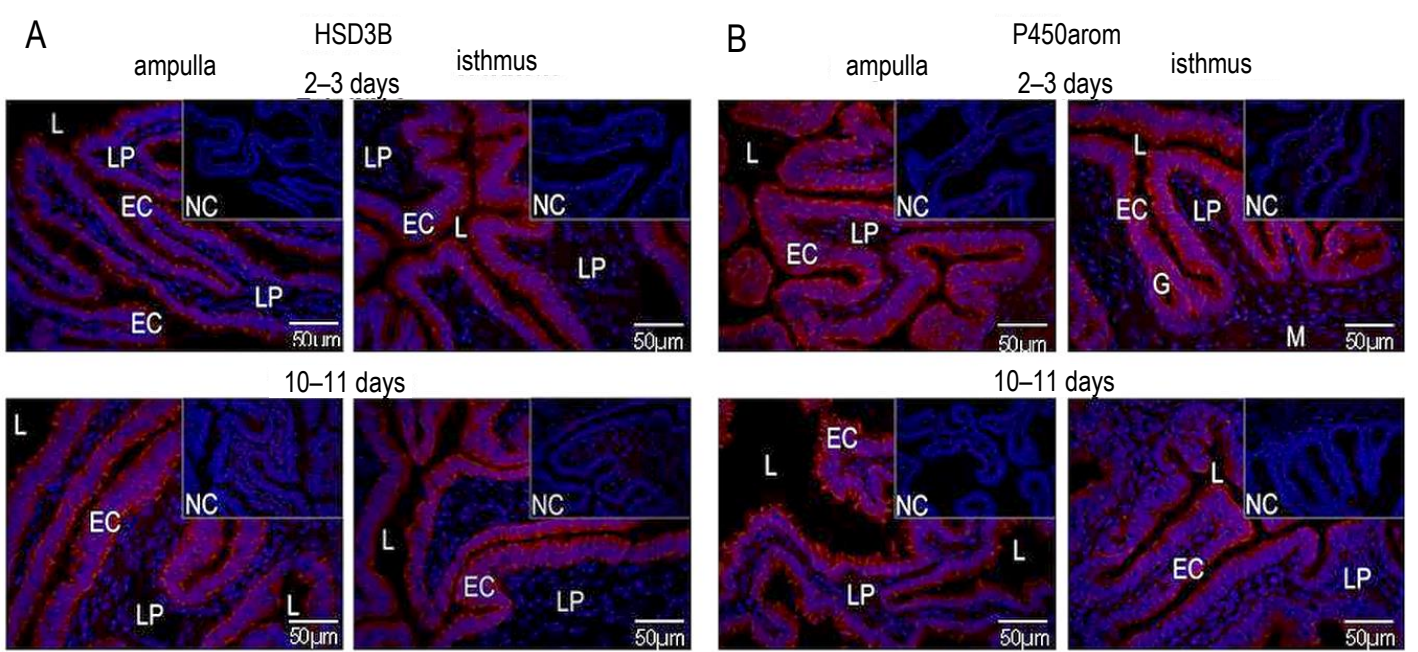

$10-11$ days
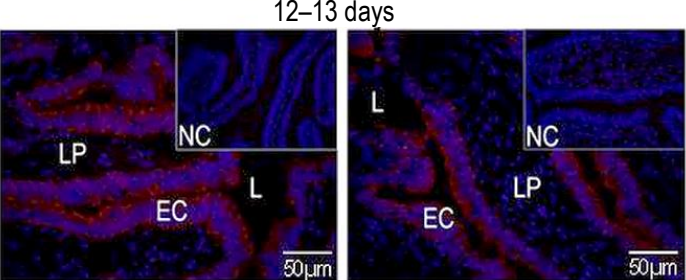

$15-16$ days
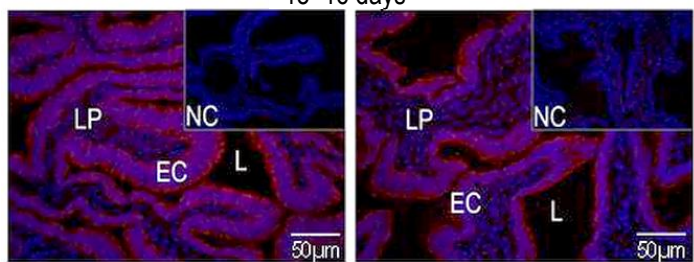

18-20 days
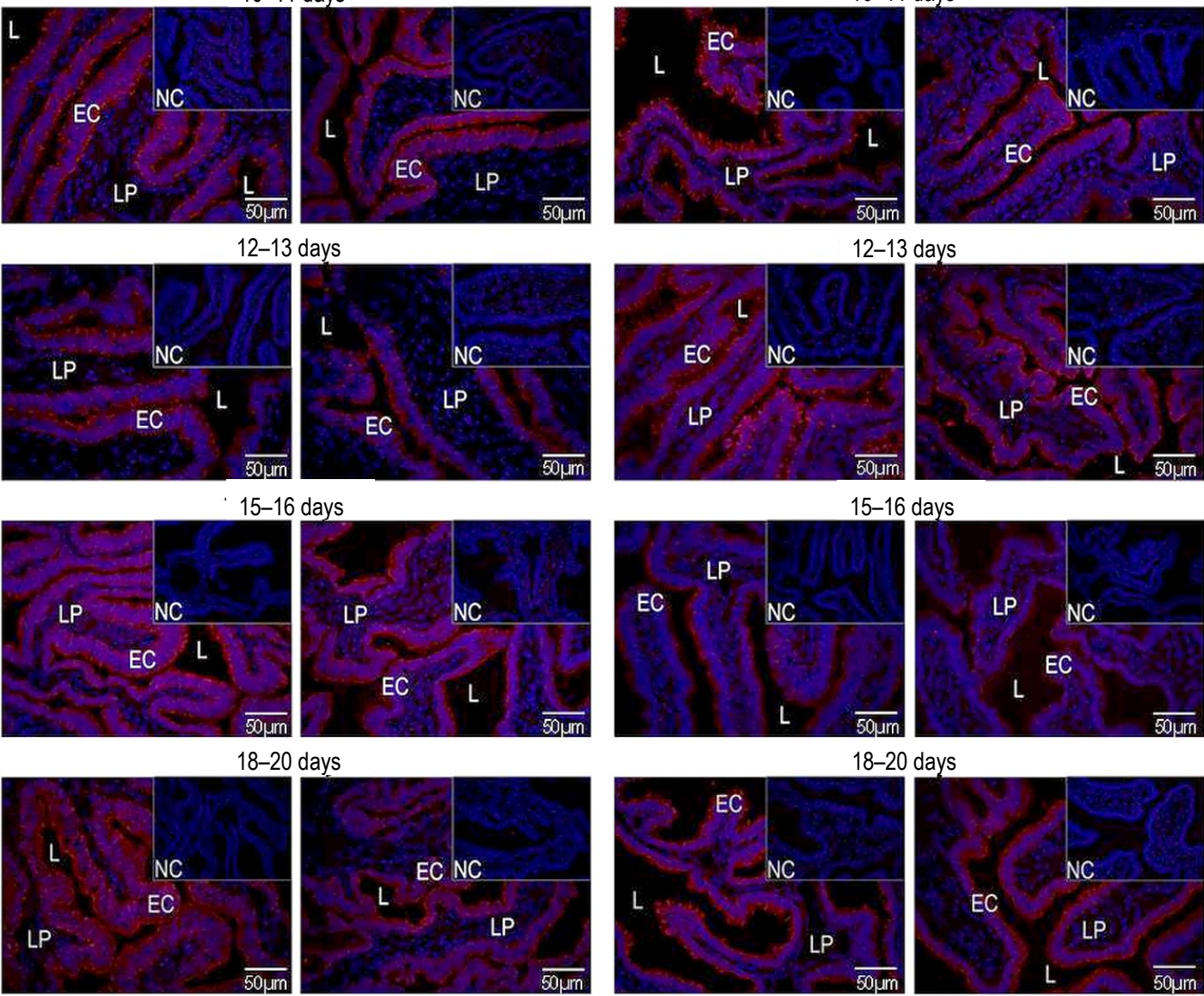

$12-13$ days

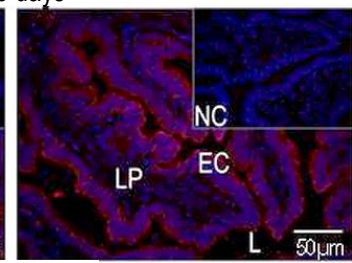

$15-16$ days

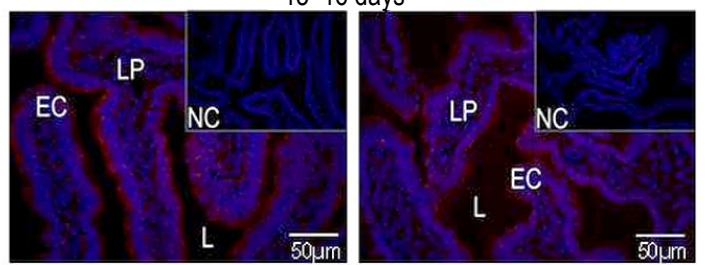

18-20 days
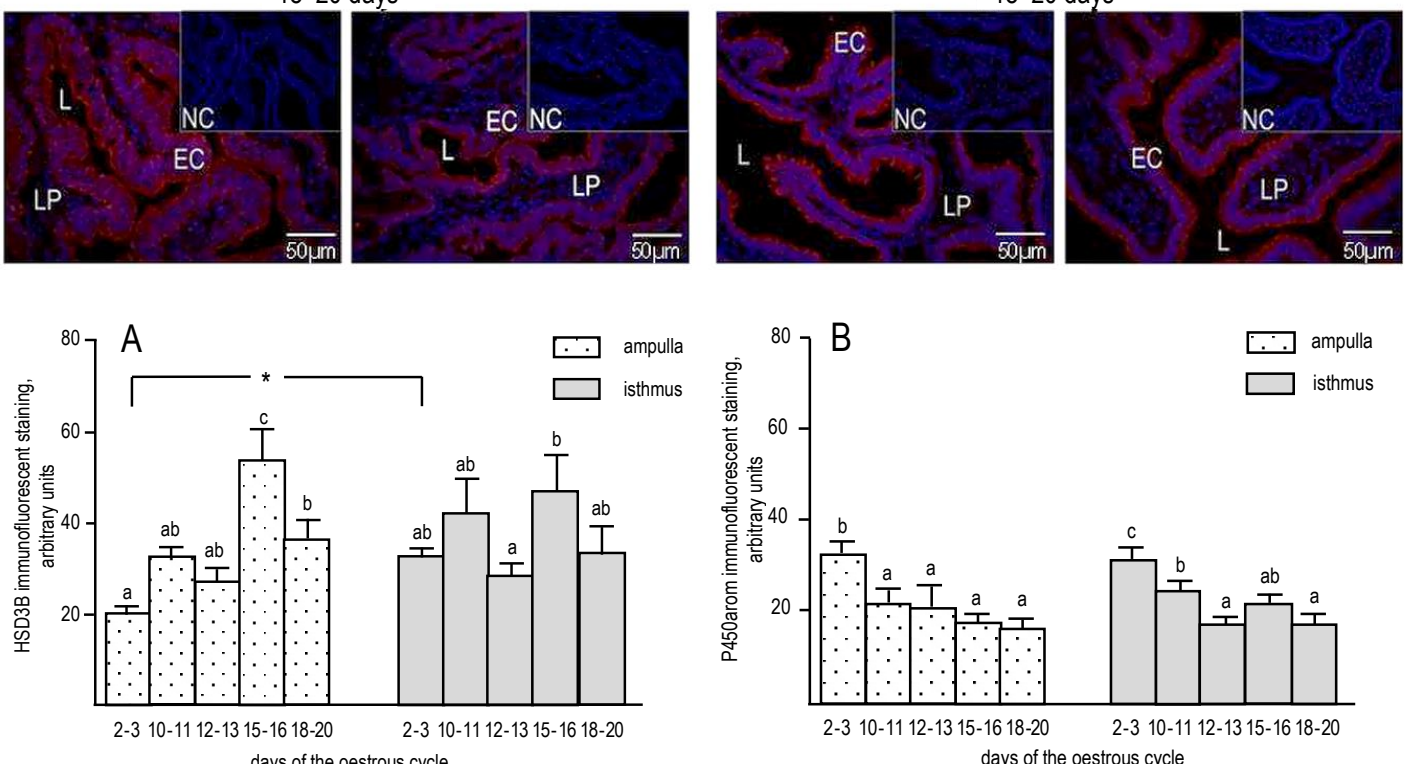

Figure 2. Representative images of immunofluorescent staining of 3ß-hydroxysteroid dehydrogenase (HSD3B; A) and P450 aromatase (P450arom; B) proteins in the epithelial cells (EC; confirmed by 4',6-diamidino-2-phenylindole (DAPI) staining) of ampulla and isthmus of oviducts harvested from gilts during the oestrous cycle on days 2-3,10-11, 12-13,15-16 and 18-20 ( $n=5$ per period). Pictures were taken at the $500 x$ magnification and fluorescence intensity was examined with Cell ${ }^{\wedge} \mathrm{F}$ software version 3.4 (Olympus, Shinjoku, Tokyo, Japan). Immunofluorescent staining was measured in each tissue slice in randomly chosen eight regions of interest in four technical replicates within five biological replicates per studied day of the oestrous cycle; The very weak positive signals of HSD3B and P450arom proteins in lamina propria (LP) and tunica muscularis (M) as well as lack of signals in lumen (L) were observed; $\mathrm{G}$ - oviductal gland; NC - negative control; abc - bars with different superscripts are significantly different at $P<0.05$ for ampulla or isthmus separately; ${ }^{*}$ - indicates significant difference between ampulla and isthmus during the same days of the oestrous cycle 


\section{Steroid hormones concentration in oviductal flushings}

Progesterone concentration in oviductal flushings ranged from $154.5 \pm 34.9$ to $960.2 \pm 367.2 \mathrm{pg} \cdot \mathrm{ml}^{-1}$ and was similar from days $2-3$ to $15-16$ and then it decreased $(P<0.05)$ on days $18-20$ of the oestrous cycle (Figure 3A). Androstenedione concentration ranged from $412.2 \pm 132.8$ to $726.4 \pm 108.4 \mathrm{pg} \cdot \mathrm{ml}^{-1}$ and was elevated $(P<0.05)$ on days $2-3$ and $18-20$ in comparison to values observed on days $10-11,12-13$ and 15-16 (Figure 3B). Concentration of E2 ranged from $59.0 \pm 7.1$ to $110.4 \pm 14.4 \mathrm{pg} \cdot \mathrm{ml}^{-1}$ and was greater $(P<0.05)$ on days $12-13$ and $18-20$ than during other days of the oestrous cycle (Figure $3 \mathrm{C}$ ).
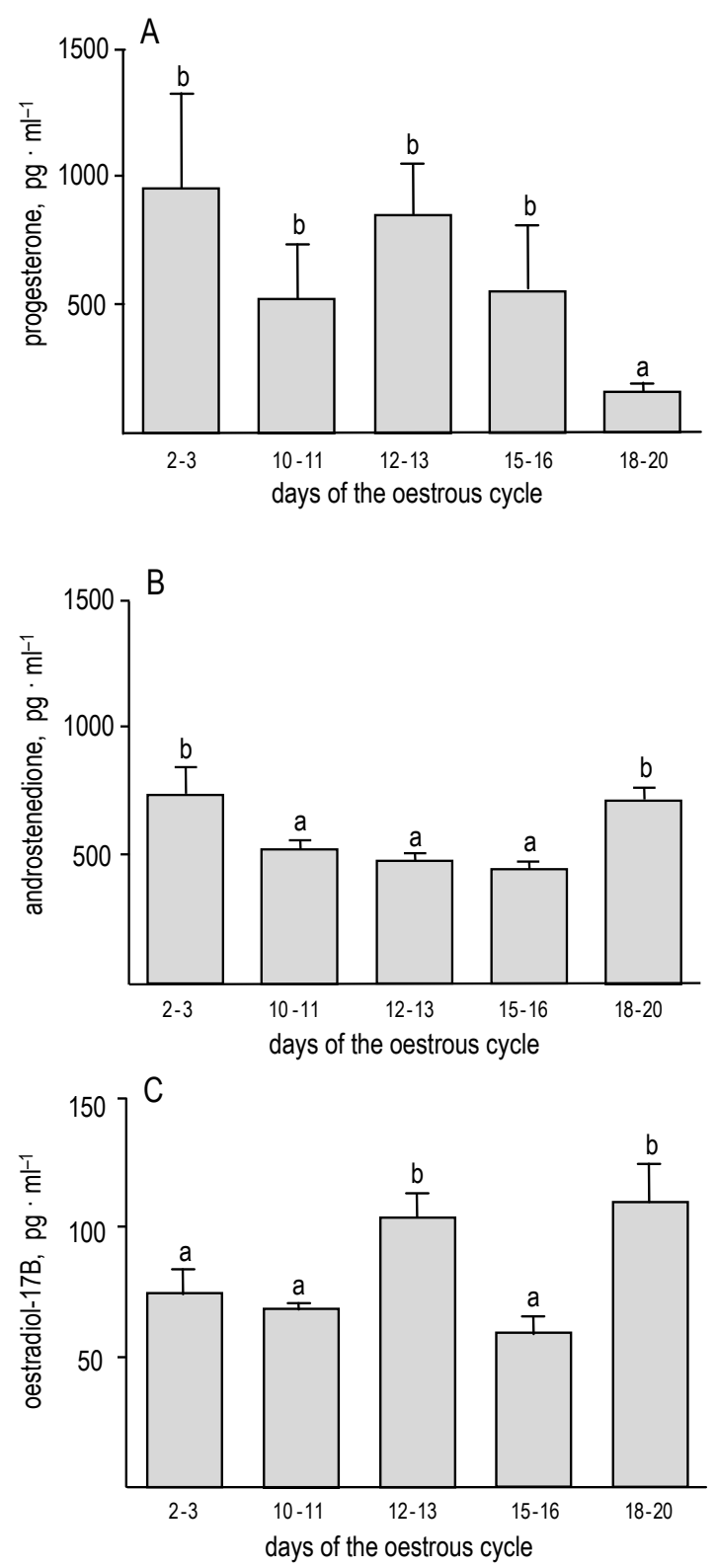

Figure 3. Progesterone (A), androstenedione (B) and oestradiol-17 $\beta$ (C) concentrations in oviductal flushings of gilts during the oestrous cycle $(n=5$ per period). Mean \pm SEM; ab - bars with different superscripts are significantly different at $P<0.05$

\section{Discussion}

In this study we have demonstrated the expression of HSD $3 B$ and CYP19 mRNA and their proteins in porcine oviduct during the oestrous cycle. The obtained data suggest that steroid hormones can be synthesized de novo in the oviduct during the luteal and the follicular phases of the oestrous cycle in pigs. The expression of the studied mRNA and proteins in ampulla and isthmus of the porcine oviduct depends on the day of the oestrous cycle. It is interesting, that despite the functional and ultrastructural differences between ampulla and isthmus (Rodriguez-Martinez et al., 1982; Hunter 1991, 2012; Yaniz et al., 2006), expression of steroidogenic enzymes between these compartments of the oviduct did not differ substantially, and moreover, the expression of HSD3B and P450arom proteins in ampulla and isthmus was correlated. We have also demonstrated that P4, A4 and E2 concentrations in oviductal flushings are depended on the stage of the oestrous cycle. Therefore, it can be postulated that the steroids produced in oviduct might act within the organ in para-/autocrine manner to adjust it accordingly to the current needs.

Steroidogenic activity of the oviduct has not been studied intensively before, because it was assumed that the ovaries are the main source of steroid hormones (Hunter et al., 1999; Buhi, 2002; Hunter, 2012). However, the synthesis of steroids in the mare oviduct has been recently reported by Nelis et al. $(2015 \mathrm{a}, \mathrm{b})$ who also observed that it was evaluated only during periovulatory period. In the contrary, in our study, the expression of steroidogenic enzymes and concentration of P4, A4 and E2 have been evaluated throughout the entire oestrous cycle. Moreover, in our study HSD3B and P450arom were immunolocalized in the epithelial cells. Similarly, in human fallopian tube, during tubal pregnancy, aromatase P450 was localized in epithelial cells ( $\mathrm{Li}$ et al., 2003). However, in the mare, HSD3B and P450arom proteins are expressed also in smooth muscle cells lining the small oviductal veins and arteries, in the lamina propria muscularis and in the surrounding connective tissue. Thus, the distribution of steroid enzyme proteins in oviductal compartments of various species seems to be different.

The present study has demonstrated changes in mRNA and protein levels for two steroidogenic enzymes, HSD3B and P450arom, in both ampulla and isthmus throughout the oestrous cycle in pigs. The greatest expression of mRNA and protein was observed during early-luteal (days 2-3), late-luteal (days 15-16) and follicular phase (days 18-20) 
of the oestrous cycle. The increased expression of steroidogenic enzymes may be associated with the local steroidogenesis in oviduct during periovulatory period. During this short-lasting period, cumulusoocyte complexes arrive in ampulla and sperm may appear in isthmus. The gametes maturate in this compartments of oviduct and then, are transported to the ampullary-isthmic junction for fusion/fertilization (Brüssow et al., 2008; Hunter, 2012). Based on the results of the present study we postulate that increased expression of steroidogenic enzymes causes the local production of steroid hormones which are involved in processes leading to fertilization. Furthermore, an important function of isthmus is to regulate the release of sperm to prevent polyspermy, and this process is regulated by $\mathrm{P} 4$. Therefore, high expression of HSD 3B mRNA on days 18-20 and higher HSD3B protein expression in isthmus than ampulla on days $2-3$, found in this study, may be required to regulate local $\mathrm{P} 4$ production in isthmus during periovulatory period in order to control sperm release.

The steroid hormones regulate also other processes in oviduct during the oestrous cycle. Chen et al. (2013) have demonstrated that E2 and P4 regulate different ultrastructural features of porcine oviduct epithelium cells, expression of selected genes, sperm-binding capacity and probably fluid movement patterns along the epithelium lining. Furthermore, aquaporins expression in oviduct (Skowronski et al., 2011) and spontaneous motility of organ (Rodriguez-Martinez et al., 1982) changes in the course of oestrous cycle in pigs, indicating regulation by steroid hormones. Hence, it can be suggested that, besides ovarian steroids, also locally produced oviductal steroids may be involved in the regulation of oviductal functions.

In this study, P4, A4 and E2 in the porcine oviductal flushings were found. Steroid hormones present within porcine oviduct may originate from different sources (Hunter, 2012), likely including the oviduct. We also observed that the concentration of P4, A4 and E2 in oviductal flushings varied during the oestrous cycle. Progesterone concentration in oviductal flushings was greater during the whole luteal phase (days from 2-3 to 15-16) and it declined just during the follicular phase (days $18-20$ ), while in peripheral blood decline of P4 level appears earlier - on days 15-16 of the oestrous cycle (Gleeson and Thorburn, 1973). Thus, in course of the oestrous cycle, P4 profile in oviductal flushings is different compared to that in the peripheral blood. Furthermore, the high level of E2 in flushings was found on days 12-13. This elevation of E2 may be connected with the increase of epidermal growth factor receptor (EGF-R) mRNA and protein expression observed in oviduct on day 12 of the oestrous cycle in response to E2 treatment (Wollenhaupt et al., 2001). The EGF/EGF-R system has been suggested to mediate local effects of E2 in porcine oviduct during proliferation and differentiation of oviductal tissue (Wollenhaupt et al., 2001; Chen et al., 2013).

\section{Conclusions}

For the first time, it was demonstrated that the mRNA and protein expression of $3 \beta$-hydroxysteroid dehydrogenase and $\mathrm{P} 450$ aromatase (P450) is present in the porcine oviduct and that it is depended on the stage of the oestrous cycle. Such observations were accompanied by the changes in progesterone, androstenedione and oestradiol-17 $\beta$ concentrations in oviductal flushings. Hence, it can be suggested that porcine oviduct has an ability to de novo synthesize steroid hormones which can locally regulate the functions of oviduct during the oestrous cycle in pigs.

\section{Acknowledgements}

This research was founded by Grant No. 12.610.005-300 UWM Olsztyn. The authors would like to thank Mrs. Janina Bukowska for her outstanding assistance.

\section{References}

Brüssow K.-P., Rátky J., Rodriguez-Martinez H., 2008. Fertilization and early embryonic development in the porcine fallopian tube. Reprod. Domest. Anim. 43, 245-251

Buhi W.C., 2002. Characterization and biological roles of oviductspecific, estrogen-dependent glycoprotein. Reproduction 123, 355-362

Carrasco L.C., Romar R., Avilés M., Gadea J., Coy P., 2008. Determination of glycosidase activity in porcine oviductal fluid at the different phases of the estrous cycle. Reproduction 136, 833-842

Chen S., Einspanier R., Schoen J., 2013. In vitro mimicking of estrous cycle stages in porcine oviduct epithelium cells: estradiol and progesterone regulate differentiation, gene expression, and cellular function. Biol. Reprod. 89, 54, 1-12

Ciereszko R., 1999. Radioimmunoassay of steroid hormones in biological fluids (in Polish). In: J Przała (Editor). Animal Physiology. Demonstration and Methods. UWM Press, Olsztyn (Poland), pp. 157-163

Dziekoński M., Żmijewska A., FranczakA., Kotwica G., Czelejewska W., Okrasa S., 2015. The expression of mRNAs for opioid precursors in endometrium of cyclic and early pregnant pigs; effects of IL-1 $\beta$, IL-6 and TNFa. J. Anim. Feed Sci. 24, 118-126

Franczak A., 2008. Endometrial and myometrial secretion of androgens and estrone during early pregnancy and luteolysis in pigs. Reprod. Biol. 8, 213-228 
Franczak A., Kotwica G., 2010. Androgens and estradiol-17ß production by porcine uterine cells: In vitro study. Theriogenology 73 , 232-241

Franczak A., Wojciechowicz B., Kolakowska J., Kotwica G., 2014. The effect of interleukin- $1 \beta$, interleukin- 6 , and tumor necrosis factor- $\alpha$ on estradiol-17 $\beta$ release in the myometrium: The in vitro study on the pig model. Theriogenology 81, 266-274

Georgiou A.S., Sostaric E., Wong C.H., Snijders A.P.L., Wright P.C., Moore H.D., Fazeli A., 2005. Gametes alter the oviductal secretory proteome. Mol. Cell. Proteomics 4, 1785-1796

Gleeson A.R., Thorburn G.D., 1973. Plasma progesterone and prostaglandin F concentrations in the cyclic sows. J. Reprod. Fertil. 32, 343-344

Goossens K., Van Poucke M., Van Soom A., Vandesompele J., Van Zeveren A., Peelman L.J., 2005. Selection of reference genes for quantitative real-time PCR in bovine preimplantation embryos. BMC Dev. Biol. 5, 27, doi:10.1186/1471-213X-5-27

Graddy L.G., Kowalski A.A., Simmen F.A., Davis S.L.F., Baumgartner W.W., Simmen R.C.M., 2000. Multiple isoforms of porcine aromatase are encoded by three distinct genes. J. Steroid Biochem. Mol. Biol. 73, 49-57

Hunter R.H.F., 1974. Chronological and cytological details of fertilization and early embryonic development in the domestic pigs, Sus scrofa. Anat. Rec. 178, 169-185

Hunter R.H.F., 1991. Oviduct function in pigs, with particular reference to the pathological condition of polyspermy. Mol. Reprod. Dev. 29, 385-391

Hunter R.H.F., 2012. Components of oviduct physiology in eutherian mammals. Biol. Rev. 87, 244-255

Hunter R.H.F., Petersen H.H., Greve T., 1999. Ovarian follicular fluid, progesterone and $\mathrm{Ca}^{2+}$ ion influences on sperm release from the Fallopian tube reservoir. Mol. Reprod. Dev. 54, 283-291

Killian G., 2011. Evidence that oviduct secretions influence sperm functions: A retrospective view for livestock. J. Anim. Sci. 89, 1315-1322

LaVoie H.A., King S.R., 2009. Transcriptional regulation of steroidogenic genes: STARD1, CYP11A1 and HSD3B. Exp. Biol. Med. 243, 880-907

Li Y., Qin L., Xiao Z.-J., Wang Y.-L., Herva R., Leng J.-H., Lang J.-H., Isomaa V., Piao Y.-S., 2003. Expression of P450 aromatase and $17 \beta$-hydroxysteroid dehydrogenase type 1 at fetal-maternal interface during tubal pregnancy. J. Steroid Biochem. Mol. Biol. 87, 241-246
Nelis H., Bussche V.J., Wojciechowicz B., Franczak A., Vanhaecke L., Leemans B., Cornillie P., Peelman L., Van Soom A., Smits K., 2015a. Steroids in the equine oviduct: synthesis, local concentrations and receptor expression. Reprod. Fert. Develop. doi:10.1071/RD14483

Nelis H., Wojciechowicz B., Franczak A., Leemans B., D'Herde K., Goossens K., Cornillie P., Peelman L., Van Soom A., Smits K., 2015b. Steroids affect gene expression, ciliary activity, glucose uptake, progesterone receptor expression and immunoreactive steroidogenic protein expression in equine oviduct explants in vitro. Reprod. Fert. Develop. doi:10.1071/RD15044

Rekawiecki R., Kowalik M.K., Kotwica J., 2013. Validation of housekeeping genes for studying differential gene expression in the bovine myometrium. Acta Vet. Hung. 61, 505-516

Rodriguez-Martinez H., Einarsson S., Larsson B., Akusu M., Settergren I., 1982. Spontaneous motility of the pig oviduct in vitro. Biol. Reprod. 26, 98-104

Skowronski M.T., Skowronska A., Nielsen S., 2011. Fluctuation of aquaporin 1,5, and 9 expression in the pig oviduct during the estrous cycle and early pregnancy. J. Histochem. Cytochem. $59,419-427$

Stefańczyk-Krzymowska S., Krzymowski T., 2002. Local adjustment of blood and lymph circulation in the hormonal regulation of reproduction in female pigs - facts, conclusions and suggestions for future research. Reprod. Biol. 2, 115-132

Szafrańska B., Zięcik A., Okrasa S., 2002. Primary antisera against selected steroids or proteins and secondary antisera against Y-globulins - an available tool for studies of reproductive processes. Reprod. Biol. 2, 187-203

Wojciechowicz B., Kotwica G., Kolakowska J., Franczak A., 2013. The activity and localization of $3 \beta$-hydroxysteroid dehydrogenase/ $\Delta^{5}-\Delta^{4}$ isomerase and release of androstenedione and progesterone by uterine tissues during early pregnanacy and the estrous cycle in pigs. J. Reprod. Dev. 59, 49-58

Wollenhaupt K., Kettler A., Brüssow K.-P., Schneider F., Kanitz W., Einspanier R., 2001. Regulation of the expression and bioactivation of the epidermal growth factor receptor system by estradiol in pig oviduct and endometrium. Reprod. Fert. Develop. 13, 167-176

Yaniz J.L., Lopez-Gatius F., Hunter R.H.F., 2006. Scanning electron microscopic study of the functional anatomy of the porcine oviductal mucosa. Anat. Histol. Embryol. 35, 28-34 